\title{
Dibalik Fakta dan Mitos Fenomena Super Blue "Blood" Moon
}

\author{
Yunina Surtiana \\ Program Studi Pendidikan IPA, Sekolah Pascasarjana, Universitas Pendidikan Indonesia \\ Bandung, Indonesia \\ e-mail: yuninasurtiana@upi.edu
}

\begin{abstract}
This article discusses a natural phenomenon namely Super Blue (Blood) Moon (later to be referred as SBBM) in terms of scientific and mythical points of view. The method used in this study is literature study promoting library research as its instrument. Thus, as much literature as possible in a variety of types such as books, journals, and any articles is collected and later analyzed. Having synthesized the literature, this study finds out that in terms of science, it is a very phenomenal occurrence since there are three natural phenomena namely super moon, blood moon, and blue moon happening simultaneously. Researchers and scientists usually seize this moment for science. For instance, some of them study the temperature shift of the moon. In the meantime, in terms of mythical point of view, some beliefs starting from the moon fights with the sun, the moon is eaten by a dragon, and the moon contributes to maternal fertility, still exist among people around the world. In conclusion, there needs to be further socialization that SBBM is a scientific phenomenon and that it has nothing to do with the existing myths around the globe.
\end{abstract}

Keywords: Super Blue Blood Moon, Mystery and mystic, moon eclipse, science Philosophy

\section{Pendahuluan}

Berbicara tentang Bulan, sejak terbentuk sekitar 400 milyar tahun yang lalu, satelit yang mengelilingi bumi ini selalu mencuri perhatian kita, manusia. Kita ingin mengunjunginya, menelitinya, dan dalam beberapa kesempatan, kita kerap memujinya dalam lirik-lirik puisi atau prosa. Bulan bisa mengilhami tidak hanya burung hantu dan serigala untuk melolong, tetapi juga manusia. Elvis Presley menyanyikan lagi lagu "Blue Moon" dari Rodgers dan Hart. Dan salah satu album terlaris band rock legendaris Pink Floyd muncul tahun 1973 dengan judul "The Dark Side of the Moon." Di Indonesia ada lagu yang berjudul "Kalau bulan bisa ngomong?" karya Doel Sumbang yang dinyanyikan Nini Carlina yang populer di tahun 1990.

Sejak dulu, sudah banyak manusia yang memuja bulan. la menjadi salah satu acuan untuk menyusun ritme kehidupan dan menghitung periode waktu yang memperlihatkan simbolisme spiritual maupun astrologi. Mark Twain pernah mengatakan: "Setiap orang adalah bulan, dan memiliki sisi gelap yang tidak pernah dia tunjukkan kepada siapa pun". Sejak zaman kuno, banyak legenda beredar tentang manusia yang berubah menjadi serigala saat bulan purnama. Tapi bulan juga bisa menjadi tema komedi romantis, seperti dalam film "Moonstruck" dari tahun 1987 yang dibintangi oleh Cher dan Nicolas Cage.

Dalam banyak hal, bulan selalu dihubungkan dengan hal-hal yang indah. Lepas dari itu bulan ternyata menyimpan banyak misteri. Beragam mitos dan teori dimunculkan untuk menjawab misteri-misteri itu, termasuk teori yang tidak lazim. Namun pendaratan bersejarah di bulan pada tahun 1969 membuat bulan kehilangan sebagian mitosnya. Manusia sekarang bisa menginjak-injak bulan, bahkan membuat foto di sana. IImu pengetahuan berhasil menghapus sebagian misteri sang bulan.

Bulan merupakan satelit alami bumi dan pada saat tertentu akan tampak bulat sempurna atau disebut purnama. Selain menghiasi langit malam, bulan juga memiliki pengaruh terhadap pasang surut lain di Bumi. Tak hanya itu, satelit alami tersebut juga menjadi penyebab gerhana Matahari.

Sedangkan Gerhana bulan terjadi saat sebagian atau keseluruhan penampang bulan tertutup oleh bayangan bumi. Itu terjadi bila bumi berada di antara matahari dan bulan pada satu garis lurus yang sama, sehingga sinar Matahari tidak dapat mencapai bulan karena terhalangi oleh bumi. Gerhana bulan yang terjadi 31 Januari 2018 yang lalu adalah fenomena bulan yang luar biasa, karena untuk fenomena Supermoon, Blue Moon, dan Gerhana Bulan terjadi secara bersamaan, sehingga NASA menjulikinya Super Blue Blood Moon. Terjadinya tiga fenomena ini secara bersamaan adalah kejadian langka, terakhir kali terjadi 152 tahun lalu. 
Gerhana bulan sejak dulu sudah menjadi misteri di berbagai kawasan budaya Tak hanya penjelasan secara ilmiah, fenomena gerhana bulan juga kerap dikaitkan dengan hal-hal berbau mistis dan mitos. Di masyarakat Jawa dan Bali ada cerita tentang raksasa bernama Batara Kala yang menelan bulan atau matahari sehingga menyebabkan gerhana. Anak-anak kecil diminta berlindung di kolong tempat tidur. Kaum perempuan, khususnya yang sedang hamil diharuskan mengolesi perutnya dengan abu sisa pembakaran kayu. Untuk mengusir sang Batara Kala, warga kemudian membuat bunyi-bunyian suara gaduh dari kentongan atau lumpang (alat untuk menumbuk padi). Konon akibat suara gaduh itu Batara Kala tak jadi menelan bulan atau matahari sehingga bulan akan bersinar kembali dengan utuh.

Padahal secara ilmiah faktanya adalah, gerhana terjadi lantaran bulan masuk dalam area Umbra atau wilayah yang tergelapi oleh bayangan bumi. Pada saat gerhana yang lalu (31/1/2018), menurut Kepala LAPAN Thomas Djamaluddin, awal gerhana akan terjadi pada pukul 18:48 WIB. Saat itu bagian bawah (sisi timur) purnama mulai tergelapi oleh bayangan bumi. Pada pukul 19.52 WIB, seluruh purnama akan masuk ke bayangan inti bulan sebagai awal dari gerhana bulan total. Ini menyebabkan bulan akan menjadi gelap kemerahan. Warna merah itu sendiri disebabkan oleh pembiasan cahaya matahari oleh atmosfer bumi. Gerhana bulan total ini akan berlangsung hingga pukul 21:08 WIB, yaitu saat purnama menjelang keluar dari umbra. Setelah itu, secara perlahan cahaya purnama mulai tampak dari bagian kanan bawah, atau sebelah timur. Keseluruhan proses gerhana akan berakhir pada pukul 22:11 WIB. "Semua wilayah di seluruh nusantara akan baik untuk melihat gerhana bulan tersebut, selama pandangan tidak terhalang oleh awan saat melihat purnama," kata Thomas kepada detikINET.

Mitos dalam kontelcs mitologi-mitologi lama mempunyai pengertian suatu bentukan dari masyarakat yang berorientasi dari masa lalu atau dari bentukan sejarah yang bersifat statis, kekal. Mitos dalam pengertian lama identik dengan sejarah / historis, bentukan masyarakat pada masa nya (Iswidayati Sri, 2007). berdasarkan bentuk kesastraan yang ada, mitos di Indonesia disebarkan dan diturunkan dalam bentuk hibrida (berpadu) dengan bentuk tradisi yang lain yang sangat beragam, dan tidak dalam bentuk mite (dongeng kepercayaan) saja. Bentuk-bentuk tradisi lisan yang dimaksud misalnya (1) sage, (2) mite, (3) fable, (4) legenda, (5) dongeng, (6) epos, (7) kepercayaan rakyat, (8) serat, (9) puisi dan nyanyian rakyat, (10) ungkapan tradisional (peribahasa), (11) mantra, (12) pertanyaan tradisonal (Ika Cahyanti, Sukatman, Furoidatul Husniah, 2017). Istilah Mitos berasal dari bahasa Yunani mythos dan bahasa Belanda mite yang berarti cerita atau perkataan. Penutur mitos terlebih dahulu telah mendengar cerita tersebut dari generasi sebelumnya, biasanya terdapat penokohan para dewa yang terjadi di dunia lain (kayangan) dan dihubungkan dengan terjadinya suatu tempat, alam semesta, adat istiadat dan dongeng masa lampau lainnya (Purnama Putra, 2009).

Di kalangan masyarakat Tionghoa berkembang mitos warna merah pada bulan yang hampir menyerupai darah saat gerhana disebabkan oleh naga yang haus darah. Naga akan turun ke bumi untuk memangsa manusia. Untuk mengusir sang Naga, masyarakat di Cina kemudian membunyikan petasan. Cara lainnya yakni dengan menggelar pertunjukan seni sampai bulan kembali seperti semula. Faktanya, seperti dikutip dari BBC, malam nanti diperkirakan bulan akan ditutupi bayangan bumi yang membuatnya tampak kemerahan seperti darah, sehingga disebut 'blood moon'. Hal ini karena sinar matahari menembus atmosfer Bumi sebelum sampai ke Bulan. Gas-gas di atmosfer menyebarkan cahaya biru, dan meloloskan cahaya merah. Bulan juga akan tampak istimewa karena 14 persen lebih besar dan 30 persen lebih terang dari biasanya. Ini karena malam nanti bulan berada di jarak terdekat dengan bumi (Perigee). Mitos-mitos yang berkembang di masyarakat nyatanya bisa dibantah dengan teori ilmiah.

Artikel ini bertujuan untuk memberikan eksplanasi ilmiah tentang gerhana bulan "super blue blood moon" dalam pandangan filsafat sains. Dengan demikian dapat merubah pandangan masyarakat umum yang masih berbau mistis dan mitos tentang gerhana bulan ini dengan pemikiran yang lebih logis dan ilmiah.

\section{Metode}

Artikel ini merupakan kajian ulas balik (review) yang menggunakan pendekatan studi kepustakaan (library research) melalui penelaahan terhadap buku-buku, literatur-literatur, dan artikel ilmiah terkait. Selain itu, hasil- hasil penelitian empiric di gunakan sebagai data sekunder untuk memperkuat argumentasi yang kemudian disintesis hingga menjadi kesatuan dalam memberikan informasi. 


\section{Hasil dan Pembahasan}

Dalam media sosial dan media surat kabar dan majalah sering kita membaca berita tentang sebuah fenomena dan misteri. Kata-kaya fenomena terkesan sesuatu peristiwa yang menggambarkan sesuatu kejanggalan atau peristiwa yang tidak lazim terjadi dalam kehidupan sehari-hari.

Pengertian Fenomena adalah sesuatu fakta yang kita temukan di lapangan (Freddy Rangkuti:2011). Sedangkan menurut (Prof. Dr. Buchari Lapau, dr, MPH : 2012) fenomena adalah sesuatu hal yang bisa disaksikan oleh panca indera serta dapat dinilai dan diterangkan secara ilmiah.

Dari Wikipedia bahasa Indonesia, ensiklopedia bebas. Misteri adalah sesuatu yang belum diketahui dengan pasti dan menarik keingintahuan orang-orang. Misteri biasanya dikaitkan dengan kejadian-kejadian horor dan supranatural. Misteri sesuatu yang eksistensi atau yang kebenarannya tersembunyi dari kita atau sangat sulit dicapai.

Perbedaan antara misteri dan fenomena adalah biasanya sebuah fenomena biasanya dapat diketahui penyebabnya secara pasti atau minimal indikasi faktor penyebabnya. Karena gejala alam misalnya, tapi misteri bedanya biasanya banyak sekali tidak diketahui sumber penyebabnya. Selain dari itu fenomena dapat dilihat banyak saksi mata sedangkan misteri hanya satu dua orang dalam waktu yang berbeda.

Mitos yaitu sesuatu hal yang dipercayai oleh sebagian orang, biasa dipakai untuk menakut-nakuti, memberi peringatan, ataupun diceritakan secara berkelanjutan. Semua mitos yang ada di dunia, merupakan mitos yang telah ada sejak zaman nenek moyang, dikarenakan cerita yang terus bergulir, atau bisa saja sesuatu mitos berubah dikarenakan zaman yang terus berkembang. Bagi sebagian orang mitos merupakan sesuatu yang sudah jarang dipercaya, tapi masih juga ada yang percaya tentang mitos-mitos tertentu dan terus bergulir sampai sekarang, seperti mitos mengenai gerhana bulan, yang sampai sekarang masih dipertanyakan keberadaannya.

Dalam Kamus Besar Bahasa Indonesia, arti mitos adalah cerita suatu bangsa tentang dewa dan pahlawan zaman dahulu yang mengandung penafsiran tentang asal usul semesta alam, manusia dan bangsa itu sendir yang mengandung arti mendalam yang diungkapkan dengan cara gaib (Kamus Besar Bahasa Indonesia :1999). Sedangkan dalam Kamus IImiah Populer, mitos adalah yang berhubungan dengan kepercayaan primitif tentang kehidupan alam gaib, yang timbul dari usaha manusia yang tidak ilmiah dan tidak berdasarkan pada pengalaman yang nyata untuk menjelaskan dunia atau alam di sekitarnya (Pius A. Partanto dan M. Dahlan Al Barry : 2001).

Mitos berasal dari bahasa Yunani muthos, yang secara harfiah diartikan sebagai cerita atau sesuatuyang dikatakan seseorang. Dalam arti yang lebih luas, mitos berarti pernyataan, sebuah cerita atau alur suatu drama (Roibin:2007). Mitos ialah cerita tentang asal mula terjadinya dunia seperti sekarang ini, cerita tentang alam alam peristiwa-peristiwa yang tidak biasa sebelum (atau dibelakang) adala duniawi yang kita hadapi ini. Cerita-cerita itu menurut kepercayaan sungguh-sungguh terjadi dan dalam arti tertentu keramat. Mitos memang berbeda dengan cerita rakyat atau folklore juga dengan legenda, karena mitos tidak hanya merupakan sebuah cerita, tapi juga dipercayai adanya, dan hal itu bisa jadi berubah sesuai zamannya. Kepercayaan terhadap mitos akan terus ada, berbeda-beda dan berkembang seperti yang telah dilihat di paragraph sebelumnya, tidak hanya terjadi karena cerita yang turun temurun, tapi juga karena adanya perasaan yang terepresi terhadap diri seseorang, yang terus menerus ditekan maka perasaan yang direpresi tersebut dapat dijadikan sebuah kepercayaan.

Misteri Seputar Bulan, Dalam banyak hal, bulan selalu dikaitkan dengan hal-hal yang indah. Lepas dari itu, bulan ternyata menyimpan banyak misteri. Beragam mitos dan teori dimunculkan untuk menjawab misteri-misteri itu, termasuk teori-teori yang tidak lazim. Sejak zaman kuno, bulan purnama kerap dikaitkan dengan perilaku aneh dan gila, termasuk berjalan saat tidur, bunuh diri, aktivitas ilegal, dan berubah jadi manusia serigala. Bagaimanapun juga, kata "lunacy" (kegilaan) dan "lunatic"(gila) berasal dari dewa bulan Romawi, Luna, yang konon kerap mengendarai keretanya melintasi langit di malam gelap gulita. Selama ribuan tahun, dokter dan pakar kesehatan mental percaya bahwa ada keterkaitan antara maniak dan bulan. Hippocrates, yang dianggap sebagai bapak kedokteran modern, menulis pada abad ke-5 SM, bahwa orang akan mengalami teror dan kegilaan di malam saat ia dikunjungi Dewi Bulan.

Di Inggris abad ke-18, orang yang didakwa melakukan pembunuhan dapat meminta keringanan hukuman jika kejahatannya itu dilakukan persis di malam bulan pernama, dengan alasan kegilaan. Pada 1820-an, astronom Bavaria Franz von Paula Gruithuisen mengklaim 
telah melihat sekilas ada kota di bulan dengan teleskopnya. la menulis bahwa "warga bulan"yang tinggal di sana telah membuat bangunan, jalan, dan benteng yang canggih. Sebagian besar rekan astronomnya mencemoohnya, tapi akhirnya ada kawah kecil di bulan yang diberi nama sepertinya namanya.Selain itu, Sir William Herschel, seorang astronom dan komposer Inggris terkemuka, juga pernah mengira alien tinggal di bulan dan melakukan observasi terkait kemajuan proyek mereka.

Mungkin karena siklus menstruasi dan bulan sama panjangnya, banyak peradaban kuno percaya bahwa bulan menentukan menentukan kapan seorang perempuan hamil. Pada 1950, dokter Ceko Eugene Jonas menemukan teks astrologi kuno milik bangsa Asyura yang menyatakan bahwa perempuan mengalami fase subur pada bulan-bulan tertentu. Dari situ, ia membuat skema keluarga berencana untuk pasien-paseinnya. Menurut teori lain, yang konon dipercaya hingga sekarang, bulan purnama menyebabkan peningkatan kelahiran.

Beberapa buku fiksi ilmiah pada awal abad ke-20, termasuk The First Men in the Moon karya H.G. Wells, menggambarkan bulan berongga yang dihuni oleh sekelompok alien. Pada 1970, dua orang Soviet membuat premis yang tampaknya aneh tapi selangkah lebih maju: bulan sebenarnya adalah kendaraan luar angkasa mirip cangkang yang dibangun oleh makhluk luar angkasa dengan teknologi dan kecerdasan superior. Menurut astronom, bulan tidak akan bisa mempertahankan masa dan gravitasinya jika tidak punya inti yang padat.

Meskipun ada banyak bukti, beberapa orang percaya bahwa pendaratan Apollo ke bulan dipalsukan oleh NASA dengan membuat foto-foto indah seolah-olah itu berada di bulan. Para pendukung klaim ini berpendapat, teknologi belum cukup maju bagi astronout untuk mencapai bulan dan kembali ke rumahnya dengan selamat. Pada 2002, pensiunan astronout Buzz Aldrin, yang menjadi orang kedua yang berjalan di bulan pada 1969, pernah sangat jengkel dengan orang-orang yang mengembuskan teori konspirasi itu. Setelah Perang Dunia II, beredar rumor yang menyebut bahwa astronout Jerman telah melakukan perjalanan ke bulan dan mendirikan sebuah fasilitas rahasia di sana. Beberapa orang berspekulasi bahwa Adolf Hitler memalsukan kematiannya sendiri, melarikan diri ke bulan, dan menghabiskan sisa hidupnya di sana. Yang juga menarik, beberapa tradisi di dunia, termasuk Buddha dan cerita rakyat asli Amerika, punya cerita legenda yang mengisahkan kelinci kecil hidup di bulan.

Mitos Gerhana Bulan, Ada Mitos seputar Gerhana Bulan. Bangsa Yunani Kuno memercayai jika datangnya gerhana bulan merupakan tanda jika Dewa sedang marah dan dipercaya merupakan awal dari sebuah bencana besar. Kata gerhana (eclipse) sendiri berasal dari bahasa Yunani Kuno "ekleipsis" yang memiliki arti ditinggalkan. Mitos lainnya, seperti : (1)Bulan sedang Terluka, Beda lagi dengan yang dipercaya oleh suku Hupa di bagian utara California. Gerhana bulan disebut sebagai tanda jika bulan sedang terluka. Suku Hupa meyakini kalau bulan memiliki 20 istri dan banyak hewan peliharaan buas seperti singa dan ular.Konon ketika bulan telat memberi makan hewan peliharaannya, mereka akan menyerang bulan hingga membuatnya berdarah. Kemudian, para istri menolong bulan dan melindungi dari serangan hewan peliharaannya. (2) Bulan Dimakan Naga, Mitos bulan dimakan juga bukan hanya dipercayai oleh suku Jawa. Masyarakat Cina meyakini ketika gerhana bulan total terjadi, disebabkan oleh seekor naga yang marah dan memakan bulan. Lalu para warga akan menyalakan bunyi-bunyia In seperti petasan untuk mengusir naga tersebut. (3) Konon katanya ada racun yang tersebar ketika gerhana bulan Masyarakat Jepang dulu juga percaya tentang mitos gerhana bulan total. Sewaktu terjadi gerhana bulan total, ada racun yang disebarkan ke bumi. Makanya mereka menutup sumur-sumur atau sumber air lain supaya tidak terkontaminasi racun. (4) Gerhana dipercaya akibat dari pertikaian antara bulan dan matahari. Kita bisa mencari sisi positif dari kepercayaan ini seperti yang dilakukan masyarakat Benin dan Togo ini, Suku Batammaliba percaya gerhana disebabkan pertengkaran antara matahari dan bulan, namun masyarakat akan berusaha melerai dan mendamaikan mereka berdua. Tersirat ada filosofi bahwa kejadian alam ini merupakan momen bagi semua orang untuk bersatu dan menuntaskan pertikaian dan dendam yang pernah ada. Kepercayaan ini masih dipegang sampai sekarang sehingga masyarakat diperkirakan bakal berkumpul untuk merayakan gerhana bulan bareng di sana. (5) Saat gerhana bulan, ibu hamil harus berhati-hati. Bahkan sampai sembunyi di kolong tempat tidur. Kepercayaan yang satu ini ternyata tidak hanya ada di Indonesia saja. Banyak juga negara lain yang meyakini bahwa para ibu hamil harus berhati-hati saat gerhana bulan. Anak mereka bisa lahir sakit, cacat dan lain sebagainya jika tidak menjalankan ritual yang diharuskan.Bahkan sampai sembunyi di bawah kolong tempat tidur. Hingga masa kini masih ada masyarakat yang percaya dan mempraktikkan berbagai ritual untuk menjaga ibu hamil di kala gerhana, tapi banyak juga yang sudah meninggalkannya. 
Eksplanasi IImiah, Keingintahuan manusia akan penjelasan terhadap fenomena yang diamamti mendorong lahirnya pertanyaan-pertanyaan mengapa "why".. Ekspalansi adalah jawaban-jawaban yang diberikan terhadap pertanyaan itu. Eksplanasi menerangkan mengapa suatu fenomena terjadi. Eksplanasi menunjukkan rangkaian sebab akibat yang berakhir pada fenomena yang hendak diterangkan (Firman, 2018). Tahayul (Superstition) seringkali menjadi bagi eksplanasi terhadap fenomena alam yang diyakini oleh masyarakat awam, misalnya penjelasan terhadap sebab musabab ternjadinya gempa bumi, gerhana matahari, gerhana bulan, gunung meletus, kecelakaan, dsb. Berdasarkan dengan eksplanasi awam, ekspalanasi ilmiah menggunakan teori dan hukum ilmiah sebagai dasarnya. (Firman, 2018).

Untuk dapat menjelaskan sebuah fenomena dapat digunakan dua jenis eksplanasi, yaitu eksplanasi ilmiah dan non-ilmiah. Eksplanasi ilmiah merupakan penjelasan atau eksplanasi yang dikemukakan oleh para ilmuwan berdasarkan bukti-bukti empiris yang diperoleh melalui langkah-langkah ilmiah (Pupafis, 2013). Manoia (1980) menjelaskann bahwa eksplanasi ilmiah dapat dikembangkan dengan dua model, yaitu model eksplanasi bercorak peluang (probabilitas) dan model eksplanasi deduktif (model eksplanasi Hempel-Oppenheim). Model eksplanasi bercorak peluang menggunakan peluang secara statistik dalam mengemukakan eksplanan. Jika hukum empirik yang bersifat statistik digunakan untuk menjelaskan peristiwa statistik, eksplanasi masih disebut eksplanasi deduktif, tetapi jika hukum statistik digunakan untuk menjelaskan peristiwa khusus maka eksplanasi tersebut merupakan eksplanasi Inductive Statistical (I-S).

Model eksplanasi Hempel-Oppenheim disebut juga dengan eksplanasi Deductive Nemological (DN) yang mempersyaratkan kondisi-kondisi logis sebagai berikut (Firman, 2018): (1) Setiap ekspalanan harus secara deduktif mengarah pada eksplanandum, (2)Deduksi harus menggunakan hukum, (3)Eksplanan-eksplanan harus mempunyai konten empiris.

Eksplanasi IImiah Gerhana Bulan, Gerhana Bulan total terjadi saat keseluruhan wajah Bulan tertutup oleh bayangan Bumi. Itu terjadi bila Bumi berada di antara Matahari dan Bulan pada satu garis lurus yang sama, sehingga sinar Matahari tidak dapat mencapai Bulan karena terhalangi oleh Bumi. (Riza:2018). Dengan kata lain, gerhana Bulan total terjadi saat fase Bulan purnama. Tetapi, tidak setiap Bulan purnama akan terjadi gerhana Bulan total. Hal ini disebabkan karena orbit Bulan miring 5 derajat saat mengelilingi Matahari. Pada 31 Januari 2018 yang lalu, bidang orbit Bulan berpotongan langsung dengan ekliptika Bumi, membuatnya akan masuk bayangan umbra Bumi sehingga Bulan akan tergerhanai dalam peristiwa gerhana Bulan total. Menariknya, gerhana Bulan total 31 Januari 2018 ini memiliki banyak keistimewaan, yaitu : Terjadi Saat Supermoon, Posisi Bulan pada saat gerhana Bulan total 31 Januari 2018 akan bertepatan pada momen ia mencapai titik perigee, atau jarak terdekat dengan Bumi. Hal ini jelas akan membuat Bulan tampak lebih besar dan lebih terang di langit malam. Para astronom menyebutnya sebagai Bulan purnama perigee, namun tampaknya kini lebih akrab disebut sebagai Supermoon. Supermoon 31 Januari 2018 akan membawa Bulan berada pada jarak sekitar 360.000 kilometer jauhnya dari Bumi. Hal itu akan membuat Bulan tampak dengan diameter sudut sebesar 33'09", cukup besar bila dibandingkan Bulan purnama yang terjadi pada biasanya.

Supermoon sendiri bisa terjadi karena jalur orbit Bulan saat mengelilingi Bumi tak melingkar sempurna, melainkan lonjong. Itu artinya, Bulan bisa saja berada ada jarak terdekat dan terjauh dengan Bumi. Bila itik terdekat Bulan dengan Bumi disebut perigee, maka titik terjauhnya disebut apogee.

Terjadi Saat "Blue Moon" , Bukan, Bulan tidak akan tampak berwarna biru. Blue Moon atau Bulan Biru hanyalah istilah untuk menyebut Bulan purnama kedua yang terjadi pada satu bulan kalender masehi. Pada Januari 2018 mendatang, fase Bulan purnama akan terjadi dua kali, yang pertama tanggal 2 Januari, dan yang kedua pada 31 Januari. Bulan purnama kedua tersebut bertepatan dengan peristiwa gerhana Bulan total! Secara astronomis, Bulan Biru terjadi pada pukul 20:27 WIB, saat puncak gerhana Bulan total terjadi.

Bulan Biru yang Semerah Darah, Alih-alih berwarna biru, pada puncak gerhana Bulan total terjadi justru ia akan muncul dalam rona kemerahan, yang kadang disebut semerah darah. Tapi, tahukah Anda mengapa gerhana Bulan total justru membuat Bulan tampak merah? Bukankah seharusnya gelap karena cahaya Matahari yang menyinarinya terhalang oleh Bumi kita?

Bumi memang menghalangi Bulan dari Matahari, tapi walaupun cahaya Matahari yang seharusnya menyiari Bulan telah tertutup oleh Bumi saat puncak gerhana total terjadi, ternyata atmosfer Bumi lah yang berperan dalam membiaskan cahaya merah dari Matahari, sehingga Bulan tidak tampak gelap total, melainkan merah. Jika Bumi tidak memiliki atmosfer, maka saat 
Bulan berada sepenuhnya di dalam bayangan Bumi saat gerhana total terjadi, Bulan akan tampak gelap dan bahkan mungkin tak terlihat. Namun berkat atmosfer Bumi, kenampakan Bulan pun akan jauh lebih indah.

Atmosfer Bumi sendiri meluas sekitar 80 kilometer di atas permukaan Bumi. Selama gerhana Bulan total, saat Bulan masuk dalam bayangan umbra Bumi, ada lingkaran yang melingkar di sekitar Bumi bila kita melihatnya dari permukaan Bulan, yang tidak lain merupakan cincin atmosfer kita. Sinar Matahari terdiri dari berbagai frekuensi. Saat sinar Matahari menerobos atmosfer kita, cahaya berfrekuensi tinggi seperti hijau, biru, dan ungu lebih mudah dihamburkan molekul atmosfer Bumi dibandingkan cahaya berfrekuensi rendah seperti cahaya kuning, oranye dan merah. Penghamburan cahaya berfrekuensi tinggi ini menyebabkan langit berwarna biru di kala siang.

Dengan begitu, cahaya kuning, oranye, dan merah akan dengan mudah melewati atmosfer dengan jalur yang lurus dan hampir tidak akan memantul jika berinteraksi dengan molekul gas di atmosfer. Pembiasan atmosfer akan mengubah arah cahaya tersebut ke arah umbra Bumi, atau bayangan gelap Bumi. Jika ada objek langit di umbra, seperti Bulan saat gerhana total misalnya, maka cahaya yang terbiaskan akan menyinari Bulan dan dipantulkan menuju sisi malam Bumi (lokasi pengamatan kita). Ketika kita mengamatinya, kita akan melihat warna merah pada Bulan. Sayangnya, Super-Red-Blue-Moon ini terjadi saat musim hujan sedang berlangsung di Indonesia. Dengan begitu, pengamatan peristiwa langka ini terancam terhalang awan atau bahkan lokasi pengamatan Anda sedang diguyur hujan.

Bagaimana cara melihatnya? Fenomena 'super blue blood moon' dapat diamati dengan mata telanjang. Bulan purnama akan terlihat berwarna merah dan lebih besar dari biasanya. Kepala Lapan Thomas Djamaluddin menerangkan, mula-mula hanya sisi timur dari bulan purnama akan kelihatan; kemudian Bulan tampak penuh pada fase total sekitar pukul 19:52 WIB sampai 21:08 WIB. Proses gerhana berakhir dengan lepasnya purnama dari bayangan Bumi pada pukul 22:11 WIB.

Apa dampaknya terhadap Bumi? Menurut kepala Lapan Thomas Djamaluddin, pada 31 Januari efek Bulan purnama terhadap Bumi akan jauh lebih kuat dari biasanya. Gravitasi bulan dan matahari memengaruhi pasang air laut. Ketika terjadi gerhana bulan - yang mana posisi Bumi berada di tengah matahari dan bulan - ditambah jarak bulan yang sangat dekat dengan bumi, pasang air laut akan mencapai maksimum. Dampak ini dapat dirasakan di daerah pantai yang landai, seperti di beberapa daerah di pantai utara Jawa. "Jika terjadi cuaca buruk di laut yang menimbulkan gelombang tinggi, banjir rob akan melimpas semakin jauh ke daratan," kata Thomas. la menambahkan, dampak lainnya yaitu jika terjadi banjir akibat hujan lebat di daratan, banjir akan lama surutnya karena dampak pasang maksimum.

Apa yang dilakukan para ilmuwan untuk memanfaatkan fenomena langka ini? Bagi para ilmuwan di badan antariksa Amerika Serikat NASA, gerhana pada 31 Januari menjadi kesempatan untuk mengamati apa yang terjadi ketika permukaan Bulan mendingin dengan cepat. Ketika gerhana bulan, penurunan temperaturnya begitu drastis seakan-akan permukaan Bulan berubah dari sepanas oven menjadi sedingin freezer hanya dalam beberapa jam. Hasil pengamatan dalam kondisi ini akan membantu mereka memahami karakteristik regolit yaitu campuran tanah dan batuan di permukaan Bulan dan perubahannya dari waktu ke waktu. Selama gerhana, para ilmuwan juga akan mengamati Bulan dengan menggunakan kamera termal, mempelajari wilayah yang biasanya tak terlihat. Meski demikian, keindahan bulan malam itu patut diwaspadai. Khususnya untuk transportasi di pelabuhan dan pesisir, serta aktivitas pertanian yang dapat terganggu.

Kepala BMKG Dwikorita Karnawati mengatakan, posisi bumi yang berada segaris dengan matahari dan bulan mengakibatkan gravitasi bulan dan matahari terintegrasi. Akibatnya, pasang air laut menjadi maksimal. "Pasang air laut mencapai 1,5 meter, meski juga dapat terjadi air laut surut 100 sampai 110 sentimeter pada tanggal 30 Januari hingga 1 Februari 2018," kata Dwikorita di kompleks gedung BMKG, Jakarta, Senin (29/1/2018). Perubahan muka air laut tersebut akan terjadi di sejumlah tempat, antara lain di Sumatera Utara, Sumatera Barat, selatan Lampung, utara Jakarta, utara Jawa Tengah, utara Jawa Timur, dan Kalimantan Barat".

Kami minta untuk diwaspadai karena fenomena Super Blue Blood Moon dapat mengganggu transportasi akibat adanya rob atau pasang maksimum, dan juga dapat dapat mengganggu aktivitas petani garam, perikanan darat serta kegiatan bongkar muat di pelabuhan, " ujar Dwikora. 


\section{Simpulan}

Gerhana Bulan terjadi ketika Matahari-Bumi-Bulan berada dalam satu garis lurus, atau juga dikenal dalam segaris syzygy. Peristiwa ini akan membuat cahaya Matahari yang biasa diterima Bulan akan terhalang oleh Bumi. Sehingga yang tersisa hanyalah rona kemerahan dari atmosfer Bumi yang terbiaskan di permukaan Bulan; membuatnya berubah warna menjadi semerah darah alias blood moon. Gerhana Bulan sendiri bukan peristiwa yang langka. la terjadi saat bidang orbit Bulan berpotongan dengan bidang ekliptika Bumi. Tidak adanya gerhana setiap bulan kalender dikarenakan Bulan mengorbit Bumi dalam orbit yang miring lima derajat. Jadi, bisa saja Bulan lebih tinggi lima derajat dari ekliptika, bisa juga di bawah lima derajat dari ekliptika. Walau demikian, dalam satu tahun kita bisa melihat setidaknya dua gerhana Bulan (dan dua gerhana Matahari). Seperti yang akan terjadi pada tahun 2018. Gerhana Bulan bukanlah pertanda bencana. la murni hanya merupakan keselarasan kosmis yang terjadi antara Matahari-Bumi-Bulan. Peristiwa ini sangat aman ditonton dan bahkan mungkin akan membuat Anda takjub saat mengamatinya. Jadi tidak perlu khawatir dan waspadalah terhadap berita dan informasi hoaks.

Fenomena Blue Blood Supermoon pada 31 Januari 2018 kemarin adalah kejadian alam spektakuler nan langka. Dimana terjadi bertepatan dengan Gerhana Bulan Total, yaitu posisi matahari, bumi dan bulan berada pada satu garis lurus. Kejadian Gerhana Bulan Total dapat diamati di sebagian besar wilayah Indonesia. "Fenomena ini merupakan fenomena langka karena akan terulang lebih dari 100 tahun untuk di Amerika, sementara wilayah Indonesia 36 tahun (30-31 Desember 1982) sehingga masyarakat diharapkan melihat atau mengamati fenomena ini dan bukan dijadikan sesuatu yang menakutkan.

Terlepas kelangkaan dan kespektakulerannya, sejumlah orang mempercayai bahwa fenomena Blue Blood Supermoon bermakna spiritual dan ramalan yang terselubung, namun kita tetap harus memaknainya fenomena Super Blue Blood Moon itu sebagai fenomena kejadian alam biasa dimana tetap kita harus mengaungkan keagungan dan kebesaran Tuhan YME, karena berdasarkan fakta ilmiah pun tidak ada hal yang istimewa selain kejadian alam di dunia ini.

\section{Daftar Pustaka}

Buku el. (2018). Gerhana Bulan Total Referensidari MrEclipse.com, Timeanddate.com, In-thesky.org Space.com, Universetoday.com

Firman, H. (2018). Filsafat Sains. Program Studi Pendidikan IPA. Sekolah Pasca Sarjana UPI.

Ika Cahyanti, Sukatman, Furoidatul Husniah. 2017. Mitos dalam Ritual Ruwatan Masyarakat Madura di Kecamatan Gending Kabupaten Probolinggo. Jurnal Edukasi Universitas Jember, Vol. 4, No. 13-19.

Iswidayati Sri. 2007. Fungsi mitos dalam kehidupan sosial budaya masyarakat pendukungnya. Harmonia Jurnal Pengetahuan dan Pemikiran Seni. Vol. 8, No.2.

Ladyman, J. (2002). Understanding Philophy of Science. London: Routledge.

Manoia, V. J. (1986). What is Science? : Introduction to the structure and methodology of science. Lenham, MD: University Press of America.

Muharam Riza.(2018). Istimewanya gerhana bulan total 31 Januari 2918. Terdapat dalam http://www.infoastronomy.org/2017/10/istimewanya-gerhana-bulan-total-31-januari2018.html.

Pius A. Partanto dan M. Dahlan Al Barry, Kamus Imiah Populer, (Surabaya: Arkola, 2001).

Purnama Putra. 2009. Mitos dan Kearifan Lokal. Jurnal PendarPenda. Vol. 2, No. 4.

Pupafis. (2013). Ekspalanasi ilmiah dan eksplanasi pedagogis. Terdapat http://momentumsudutdanrotasibendategar.blogspot.co.id.

Ridzky Firmansyah Fahmi. 2017. Mitos danau sebagai pelestari lingkungan. Jurnal Pendidikan Bahasa dan Sastra Indonesia Universitas Swadaya Gunung Jati (UNSWAGATI). Vol. 4, No. 2.

Roger M. Keesing, Cultural Anthropology: A Contemporary Perspective, diterjemahkan R.G. Soekadijo, Antropolgi Budaya: Suatu Perspektif Kontemporer. Edisi Kedua. (Jakarta: Penerbit Erlangga, 1992). 
Roibin, Agama dan Mitos: Dari Imajinasi Kreatif Menuju Realitas Yang Dinamis, dalam (EI Harakah Jurnal Budaya Islam, Vol.9 no 3, September -Desember 2007).

Tim Penyusun Kamus Pusat Pembinaan dan Pengembangan Bahasa, Kamus Besar Bahasa Indonesia. (Jakarta: Balai Pustaka, 1999).

Yusdani. 2010. Menggali makna mitos dalam sastra dan budaya nusantara. Millah Jurnal Studi Agama.Vol.10.No.1. 